\title{
Comparative Proteome Analysis of Cyanidin 3-O-glucoside Treated Helicobacter pylori
}

\author{
Sa-Hyun Kim ${ }^{1}$ and Jong-Bae Kim ${ }^{2, \dagger}$ \\ ${ }^{I}$ Department of Clinical Laboratory Science, Semyung University, Jecheon 27136, Korea \\ ${ }^{2}$ Department of Biomedical Laboratory Science, College of Health Sciences, \\ Yonsei University, Wonju 26493, Korea
}

\begin{abstract}
Some virulence proteins of Helicobacter pylori, such as vacuolating cytotoxic protein A (VacA) and cytotoxinassociated gene protein $\mathrm{A}(\mathrm{CagA})$ have been reported to be causative agents of various gastric diseases including chronic gastritis, gastric ulcer or gastric adenocarcinoma. The expression level of these virulence proteins can be regulated when H. pylori is exposed to the antibacterial agent, cyanidin 3-O-glucoside (C3G) as previously reported. In this study, we analyzed the quantitative change of various virulence proteins including CagA and VacA by C3G treatment. We used 2-dimensional electrophoresis (2-DE) to analyze the quantitative change of representative ten proteome components of H. pylori $60190\left(\mathrm{VacA}^{+} / \mathrm{CagA}^{+}\right.$; standard strain of Eastern type). After 2-DE analysis, spot intensities were analyzed using ImageMaster ${ }^{\mathrm{TM}}$ 2-DE Platinum software then each spot was identified using matrix assisted laser desorption ionization-time of flight mass spectrometry (MALDI-TOF-MS) or peptide sequencing using Finnigan LCQ ion trap mass spectrometer (LC-MS/MS). Next, we selected major virulence proteins of $H$. pylori among quantitatively meaningful ten spots and confirmed the 2-DE results by Western blot analysis. These results suggest that cyanidin 3-O-glucoside can modulate a variety of $H$. pylori pathogenic determinants.
\end{abstract}

Key Words: Helicobacter pylori, Cyanidin 3-O-glucoside, 2-dimensional electrophoresis, VacA

\section{INTRODUCTION}

Numerous attempts have been made to identify markers for virulent $H$. pylori strains by proteomics analysis. Vacuolating cytotoxic protein A (VacA) and cytotoxinassociated protein A (CagA) have been reported as representative pathogenic determinants in $H$. pylori (Censini et al., 1996; Cover et al., 1993). Especially the genes located within the Cag pathogenicity island (Cag PAI) are thought

\footnotetext{
*Received: December 20, 2015 / Revised: December 23, 2015

Accepted: December 24, 2015

${ }^{\dagger}$ Corresponding author: Jong Bae Kim. Department of Biomedical Laboratory Science, College of Health Sciences, Yonsei University, Wonju, 26493, Korea.

Tel: +82-33-760-2423, Fax: +82-33-760-2561

e-mail: kimjb70@yonsei.ac.kr

(C)The Korean Society for Biomedical Laboratory Sciences. All rights reserved.
}

to be responsible for the increased virulence of $H$. pylori (Israel et al., 2001; Glocker et al., 1998; Meyer-ter-Vehn et al., 2000; Selbach et al., 2002). Although other bacterial factors such as urease (Megraud et al., 1992), flagella (Megraud et al., 1996), adhesin (Doig et al., 1992), and ferritin (Waidner et al., 2002) also have been reported as pathogenic determinants, understanding the cellular pathogenesis of $H$. pylori in the pathogenesis of gastric diseases, as well as identifying virulent strains, requires further studies. Currently, the complete genome sequences of $H$. pylori strains 26695 and J99 have been reported (Alm et al., 1999; Tomb et al., 1997). In addition, further genomic information is accumulating rapidly which combined with identification techniques to find disease or organism-specific markers have greatly improved our understanding of pathogenic factors in H. pylori. In this study, 2-dimensional electrophoresis (2-DE) 
and protein identification techniques were used to analyze the effect of cyanidin 3-O-glucoside on the expression of various $H$. pylori pathogenic proteins.

\section{MATERIALS AND METHODS}

\section{Cyanidin 3-O-glucoside (C3G)}

C3G (Extrasynthese; Lyon, France) was dissolved in sterile dimethyl sulfoxide (DMSO; Sigma Aldrich, St. Louis, MO, USA) as a $50 \mathrm{mM}$ stock solution and stored at $-20^{\circ} \mathrm{C}$ prior to usage.

\section{Bacterial strain and culture}

Helicobacter pylori reference strain 60190 (Eastern type: $\mathrm{CagA}^{+} / \mathrm{VacA}^{+}$) was purchased from American Type Cell Collection (ATCC; Manassas, VA, USA). Bacteria were maintained under microaerophilic conditions at $37^{\circ} \mathrm{C}$ on Brucella agar plates (Becton-Dickinson, Braintree, MA, USA) supplemented with $10 \%$ fetal bovine serum (FBS; Gibco, Long Island, NY, USA). For experiments, H. pylori were cultured in Mueller-Hinton broth (Becton-Dickinson) containing 10\% FBS under microaerophilic condition for $3 \sim 4$ days at $37^{\circ} \mathrm{C}$ and $100 \%$ humidity.

\section{Protein sample preparation \& 2-dimensional gel electro- phoresis}

The harvested samples were suspended in $0.5 \mathrm{ml}$ of 50 $\mathrm{mM}$ Tris buffer containing $7 \mathrm{M}$ urea, $2 \mathrm{M}$ thiourea, 4\% (w/v) CHAPS, and $16 \mu$ protease inhibitor cocktail (Roche Molecular Biochemicals, Indianapolis, IA, USA). For 2-DE analysis, $\mathrm{pH} 4 \sim 7$ IPG strips (Amersham, Pittsburgh, PA, USA) were used. The 2-D separation was performed on $8 \sim 16 \%(\mathrm{w} / \mathrm{v})$ linear gradient SDS-polyacrylamide gels. Protein spot detection and 2D pattern matching were carried out using ImageMaster ${ }^{\mathrm{TM}}$ 2D Platinum software (Amersham). For comparison of protein spot densities between control and treated samples, more than 20 spots throughout all gels were correspondingly marked and normalized. The quantified spots of candidate proteins were compared with the aid of histograms. To ensure reproducibility of 2-DE experiments, each sample was analyzed in triplicate.

\section{In-gel digestion with trypsin and extraction of peptides}

In-gel digestion of protein spots from Coomassie Blue stained gels was performed by ProteomeTech (Seoul, South Korea). In brief, protein spots were excised from stained gels and cut into pieces. The excised protein spots from a silver stained gel were cut into pieces and in-gel digested with trypsin.

\section{Analysis of peptides using MALDI-TOF MS and identifi- cation of proteins}

Mass measurement of tryptic peptides were carried out with a Voyager-DE STR mass spectrometer (PerSpective Biosystems, Bedford, MA, USA). Close external calibration was performed for every sample with calibration mixtures. The proteins were identified by peptide mass fingerprinting (PMF) searching, against the Swiss-Prot and NCBI databases, using the search program ProFound (http://129.85.19.192/ profound_bin/WebProFound.exe, Rockefeller University, Version 4.10.5), MASCOT (http://www.matrixscience.com /cgi/search_form.pl?FORMVER=2\&SEARCH=PMF), or MS-Fit (http://prospector.ucsf.edu/ucsfhtml4.0/msfit.htm, University of California San Francisco, Version 4.0.5).

\section{Identification of proteins by LC-MS/MS}

The resulting tryptic peptides were separated and analyzed using reversed phase capillary HPLC directly coupled to a Finnigan LCQ ion trap mass spectrometer (LC-MS/MS). For tandem mass spectrometry, a full mass scan range mode was $\mathrm{m} / \mathrm{z}=450 \sim 2000 \mathrm{Da}$. The individual spectra from MS/ MS were processed using the TurboSEQUEST software (Thermo Quest, San Jose, CA). The generated peak list files were used to query either MSDB database or NCBI using the MASCOT program (http://www.matrixscience.com). Only significant hits as defined by MASCOT probability analysis were considered initially.

\section{Western blot analysis}

H. pylori were lysed in ice-cold RIPA lysis buffer (Millipore, Billerica, MA, USA) for 30 minutes on ice and sonicated for 2 minutes with 10 second intervals (Sonicator XL-2020, Heat Systems Ultrasonics, Pittsburgh, PA, USA). 
KATO III cells $\left(5 \times 10^{6}\right)$ were plated in $10-\mathrm{cm}$ plates. Following infection, cells were washed with PBS, lysed with $150 \mu \mathrm{L}$ of RIPA buffer on ice for $30 \mathrm{~min}$. Lysates of culture dishes treated identically were pooled and clarified at $13,000 \times \mathrm{g}$ for $10 \mathrm{~min}$ at $4^{\circ} \mathrm{C}$. Protein concentration was determined by the Lowry method and quantified using NanoQuant spectrophotometer (Infinite M200, TECAN, Männedorf, Switzerland). Protein extracts were resolved on $7.5 \%, 10 \%$ or $4 \sim 15 \%$ gradient SDS-PAGE and then transferred to a nitrocellulose membrane (Millipore). Membranes were blocked with 5\% skim milk for 30 minutes and then incubated with rabbit anti-VacA polyclonal antibody (Santa Cruz Biotechnology, Santa Cruz, CA, USA), rabbit anti- $H$. pylori SecA polyclonal antibody (Kim et al., 2014) or rabbit anti-H. pylori polyclonal antibody (Kim et al., 2012). Appro- priate horseradish peroxidase-conjugated secondary antibodies (Santa Cruz Biotechnology) were used and protein bands were visualized using enhanced chemiluminescence and X-ray film. The bacterial supernatant was centrifuged at 3,000 rpm three times and filtered with $0.22 \mu \mathrm{m}$ syringe filters to remove remained all bacteria. The prepared supernatant was concentrated 10 -fold using Centricon centrifugal filters (Millipore; $3 \mathrm{kDa}$ cut-off) at 3,000 rpm for 1 2 hours at $4{ }^{\circ} \mathrm{C}$.

\section{RESULTS AND DISCUSSION}

Approximately 200 spots from silver-stained gels were recorded by the PDQUEST program. Following proteomic analysis, we selected ten quantitatively meaningful protein

Table 1. Representative virulence protein changes of C3G treated H. pylori 60190 strain

\begin{tabular}{|c|c|c|c|c|c|c|}
\hline \multirow[b]{2}{*}{$\begin{array}{l}\text { Spot } \\
\text { No. }\end{array}$} & \multicolumn{2}{|r|}{ Protein $^{a)}$} & \multicolumn{4}{|c|}{ 2-DE data ${ }^{\text {b) }}$} \\
\hline & $\begin{array}{l}\text { TIGR locus } \\
\text { name }\end{array}$ & Protein name & $\mathrm{p} I / M_{\mathrm{r}}$ & $\begin{array}{l}\text { Protein-change } \\
\text { ratio }(\%)^{\mathrm{c})} \text { after } \\
\text { C3G treatment }\end{array}$ & $\begin{array}{l}\text { Standard }^{\text {d) }} \\
\text { deviation }\end{array}$ & Reference \\
\hline 1 & HP0547 & $\begin{array}{l}\text { Cytotoxin-associated gene protein A } \\
\text { (CagA) fragment }\end{array}$ & $5.75 / 81,500$ & +252.87 & 4.31 & González L et al., 2013 \\
\hline \multirow[t]{2}{*}{2} & HP0887 & $\begin{array}{l}\text { Vacuolating cytotoxic protein A } \\
\text { (VacA) fragment }\end{array}$ & $6.20 / 95,740$ & +644.96 & 2.81 & Backert S et al., 2005 \\
\hline & HP0887 & $\begin{array}{l}\text { Vacuolating cytotoxic protein A } \\
\text { (VacA) fragment }\end{array}$ & $6.65 / 87,970$ & +2243.31 & 3.73 & \\
\hline 3 & HP0786 & $\begin{array}{l}\text { Preprotein translocase subunit } \\
\operatorname{Sec} A(\operatorname{Sec} A)\end{array}$ & $6.12 / 99,207$ & -416.24 & 1.68 & this study \\
\hline 4 & HP0072 & Urease subunit beta (UreB) & $6.09 / 61,645$ & -311.47 & 2.27 & Backert S et al., 2005 \\
\hline 5 & HP0210 & Heat shock protein 90 (Hsp90) & $5.73 / 71,230$ & -3513.95 & 4.90 & this study \\
\hline 6 & HP1205 & $\begin{array}{l}\text { Elongation factor thermo unstable } \\
(\mathrm{EF}-\mathrm{Tu})\end{array}$ & $5.36 / 43,594$ & -1144.74 & 12.71 & Israel DA et al., 2001 \\
\hline 7 & HP0809 & $\begin{array}{l}\text { Flagellar basal body protein } \\
\text { FliL (FliL) }\end{array}$ & $5.41 / 55,134$ & -714.91 & 1.69 & this study \\
\hline 8 & HР0779 & Aconitate hydratase AcnB (AcnB) & $6.44 / 118,230$ & -2547.76 & 10.23 & Backert S et al., 2005 \\
\hline 9 & HP0322 & Poly E-rich protein & $4.30 / 91,100$ & +200.71 & 3.79 & Backert S et al., 2005 \\
\hline 10 & HР0480 & GTP-binding protein & $6.80 / 68,000$ & +188.24 & 21.96 & Backert S et al., 2005 \\
\hline
\end{tabular}

a) Protein designation according to H. pylori strain NCBI (http://www.ncbi.nlm.nih.gov/), KEGG database (http://www.genome.jp/kegg/).

b) According to peptide mass fingerprinting (PMF) data were obtained from Fig. 1.

c) The ratio of protein-change amount was calculated as follows:

$$
\text { change ratio }(\%)=\frac{\Delta \text { value }(\text { protein amount w/ C3G }- \text { protein amount w/o C3G) }}{\Delta \text { value }(\text { protein amount } w / 0 \text { C3G })} \times 100
$$

d) Standard deviation of protein-change ratio in each spot was obtained from repeated five independent 2-ED analysis. 

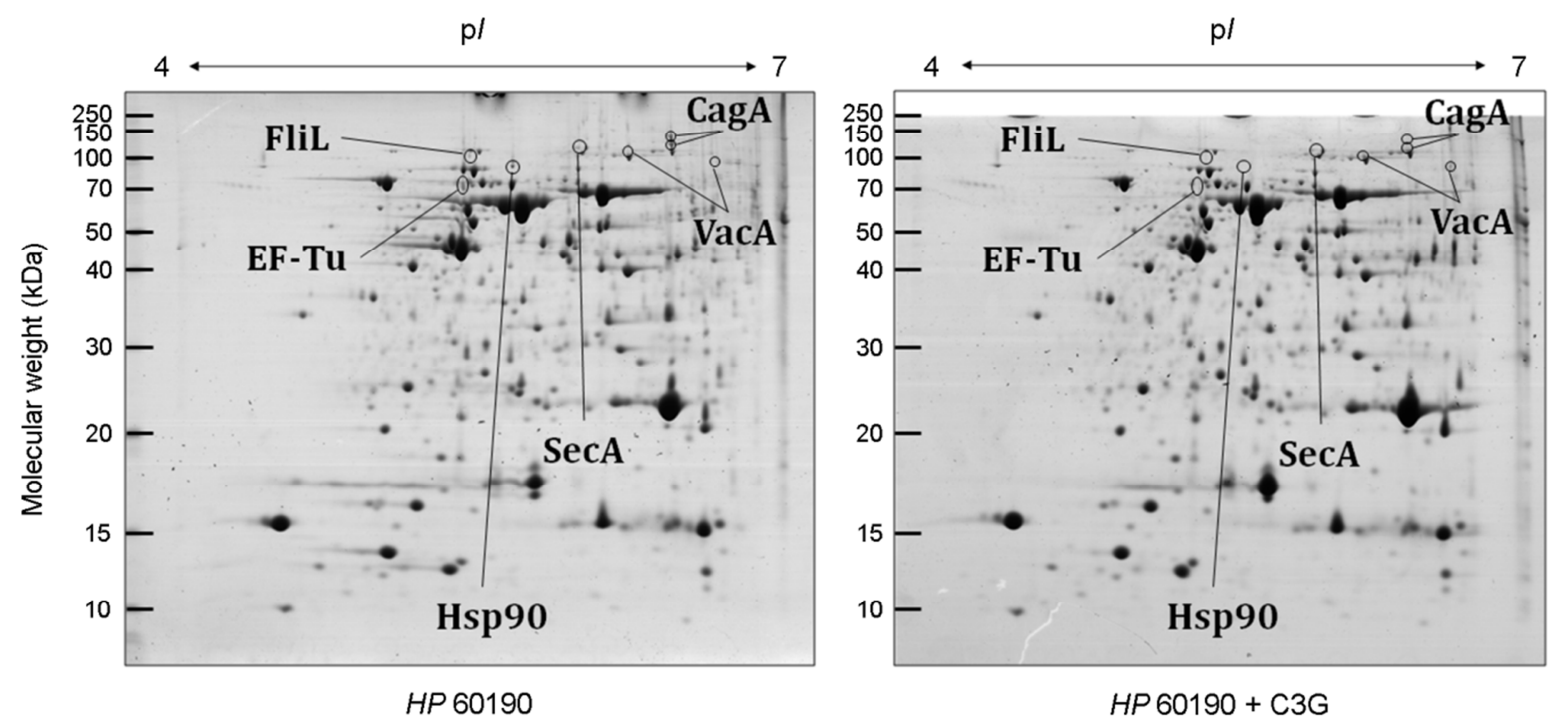

Fig. 1. A representative two-dimensional gel-electrophoresis map of H. pylori 60190 strain untreated (left panel) or treated with C3G (right panel). The spots were identified by MALDI-TOF-MS or TOF-MS. Molecular size markers (kDa) are shown on the left.

spots including CagA, VacA, protein translocase subunit A (SecA), urease subunit beta (UreB), heat-shock protein 90 (Hsp90), elongation factor thermo unstable (EF-Tu), flagella basal body-associated protein FliL (FliL), aconitate hydratase (AcnB), Poly E-rich protein, and GTP-binding protein (Fig. 1). The selected ten protein spots were changed in the 2-DE images and were identified by peptide mass fingerprinting using MALDI-TOF-MS or by peptide sequencing using LC-MS/MS (Table 1).

Among the ten quantitatively meaningful proteins we focused on six proteins - CagA, VacA, SecA, Hsp90, EF-Tu, and FliL - because these had been previously investigated as disease-specific markers and are used as landmarks to analyze clinical isolates (Park et al., 2006; Backert et al., 2005). These proteins were readily identified and their intensities measured in 2-DE gels of $\mathrm{pH} 4 \sim 10$ (Fig. 1). Representative 2-DE spot profiles of H. pylori 60190 strain among total spot profiles of protein changes were compared to reference data (Choi et al., 2002; Jungblut et al., 2000). The intensities of six target protein spots in 2-DE profiles of H. pylori 60190 standard strain are associated with clinical diseases, such as chronic gastritis, gastric ulcers, or gastric adenocarcinoma (Park et al., 2006; Backert et al.,
2005). H. pylori CagA is strongly associated with a significant increase of risk for the development of gastric disorders like ulcers, adenocarcinoma or MALT lymphoma (Censini et al., 1996). Especially, the Eastern Asian strains of H. pylori are predominantly CagA-positive, responsible for gastric diseases (Ito et al., 1997). Here, our data showed that the CagA intensity in C3G-treated group was significantly lower than the untreated group. This result suggests that CagA expression might regulated by $\mathrm{C} 3 \mathrm{G}$ (Fig. 1 and 2). $H$. pylori VacA is associated with the apoptosis and necrosis of H. pylori-infected gastric epithelial cells. It has been reported that VacA forms cytotoxic vacuoles in host cells and is a cause of gastric cell death and gastric and/or duodenal inflammation and ulcer (Rassow, 2011). The level of VacA was increased in $\mathrm{C} 3 \mathrm{G}$ treated cells (Fig. 1 and 2). This result suggests that $\mathrm{C} 3 \mathrm{G}$ down-regulated the secretion of VacA and thus resulting in accumulation of VacA in $H$. pylori cells. We investigated this phenomenon with SecAcorrelation by Western blot analysis (Fig. 3).

H. pylori Sec-related proteins are associated with bacterial type V secretion system (T5SS) (Cover, 2005). Although the mechanism of this secretory system is still under intense investigation, VacA secretion is regulated by the type $\mathrm{V}_{\mathrm{a}}$ 


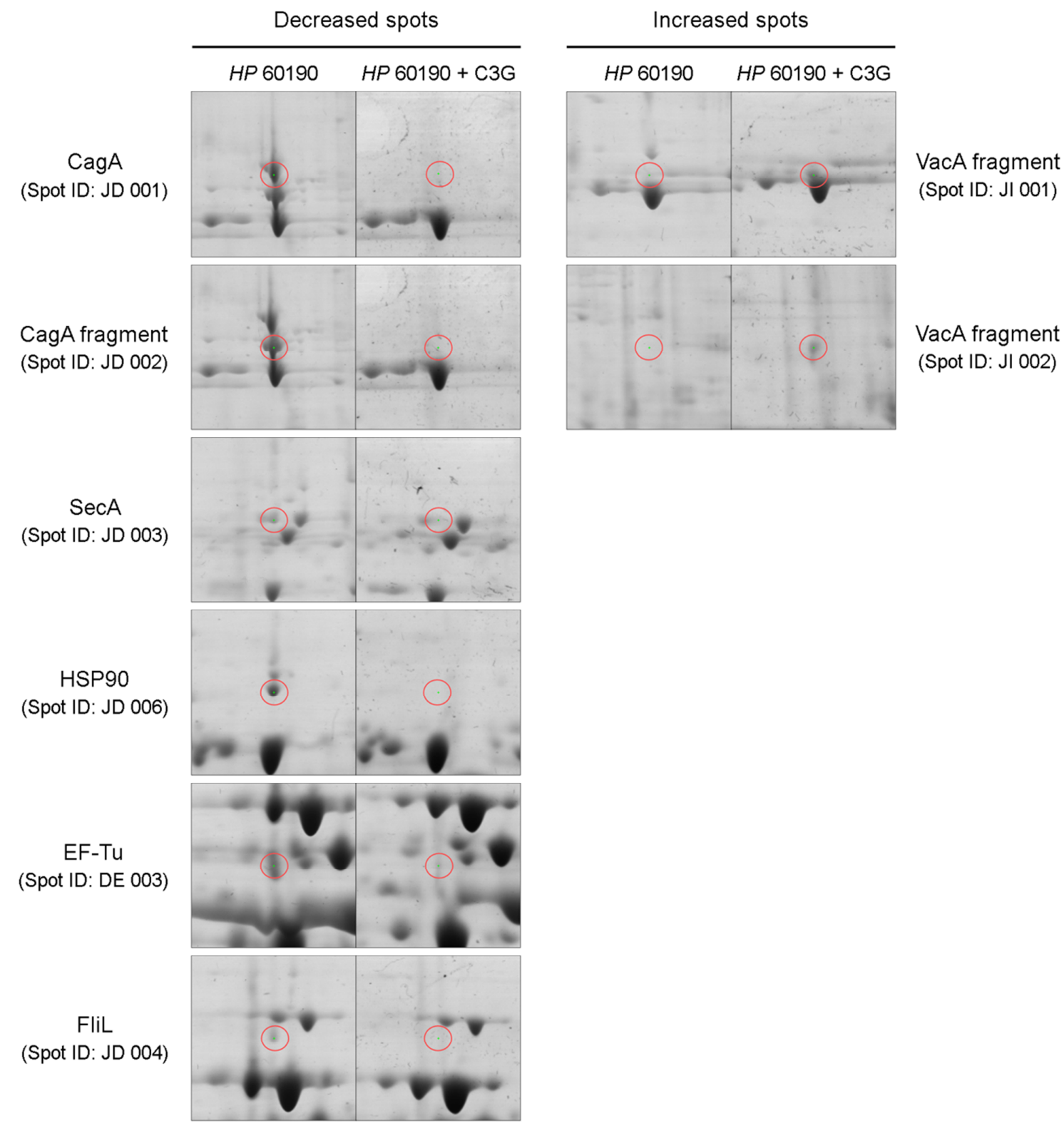

Fig. 2. Quantitative changes of major pathogenic proteins identified in this study.

secretion system $\left(\mathrm{T}_{\mathrm{a}} \mathrm{SS}\right)$ which is SecA-dependent (Cover, 2005; Shaffer et al., 2011). The SecA protein expression was decreased in $\mathrm{C} 3 \mathrm{G}$ treated group compared to the untreated group. This suggests that the decreased SecA levels might affect the accumulation of VacA in cell. H. pylori Hsp90 showed decreased levels in the $\mathrm{C} 3 \mathrm{G}$ treated group although the functional relevance is unclear at this time. H. pylori EF-Tu, the translation factor of $H$. pylori has been reported to be highly immunoreactive to both $\operatorname{IgG}$ and $\operatorname{IgA}$, and its expression level is significantly high in ulcer or chronicgastritis patients (Lock et al., 2002). In our study, the expression level of EF-Tu was significantly decreased in the $\mathrm{C} 3 \mathrm{G}$ treated group (Fig. 1 and 2). We also found that $H$. pylori FliL levels decreased after C3G treatment (Fig. 2). FliL is a transmembrane protein located adjacent to the basal body of its flagellar structure. It is thought that a bacterial- 

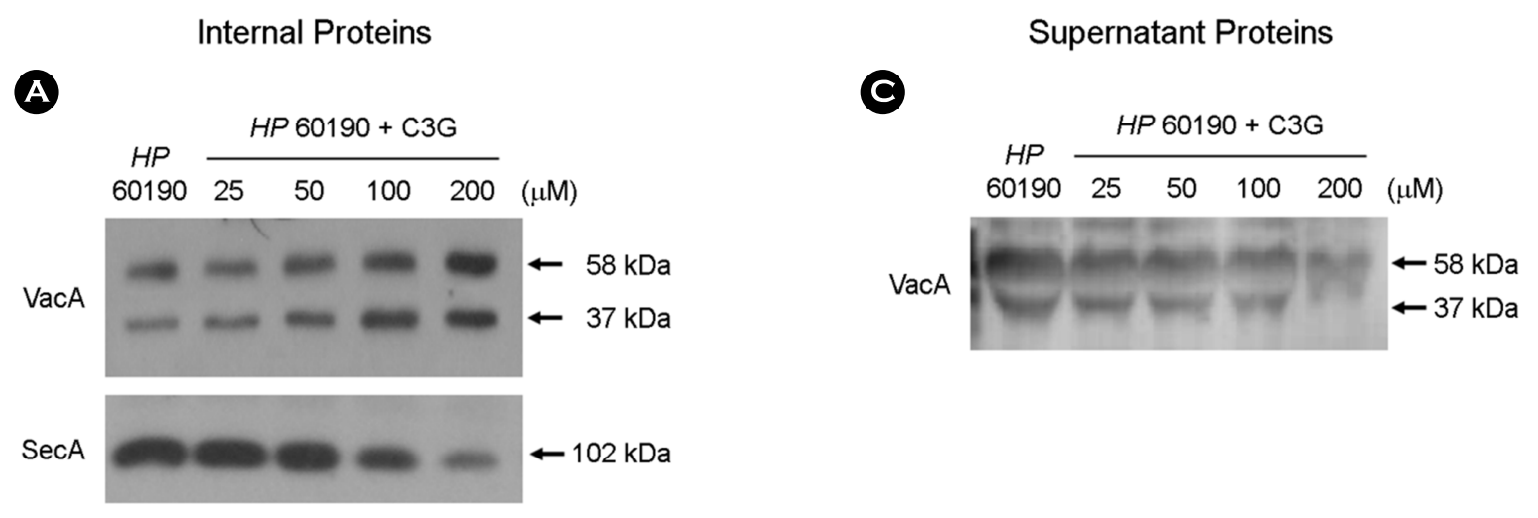

B

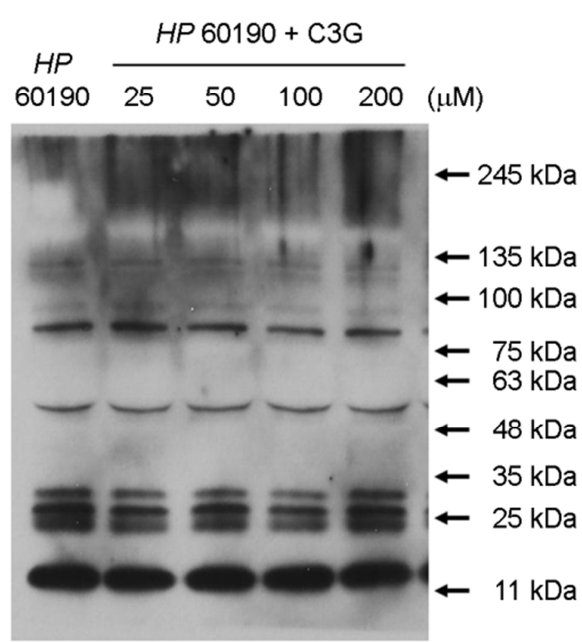

D

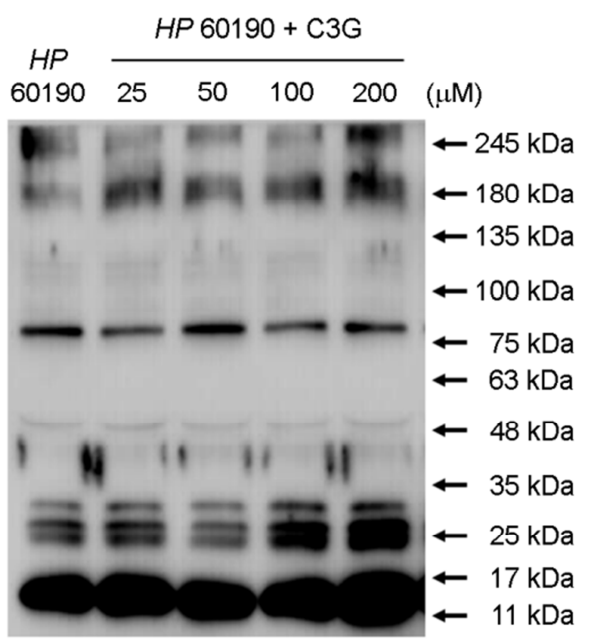

Fig. 3. Effects of cyanidin 3-O-glucoside on secretion of $H$. pylori VacA and expression of SecA. H. pylori was cultured with various concentrations $(0 \sim 200 \mu \mathrm{M})$ of $\mathrm{C} 3 \mathrm{G}$ in Mueller-Hinton broth/10\% FBS for 3 days and protein levels assessed by Western blot. (A) intracellular VacA and SecA, (B) intracellular $H$. pylori proteins reacting with rabbit anti-H. pylori polyclonal antibody, (C) secreted VacA in culture media, (D) secreted H. pylori proteins reacting with rabbit anti- $H$. pylori polyclonal antibody. Representative image from five independent experiments.

type flagellum is a motor complex composed of an extracellular helical protein filament coupled to a rotary motor embedded in the cell envelope. FliL has a single transmembrane domain near its N-terminus (Lee and Belas, 2015). The function of FliL in H. pylori is still unclear, although it has been reported that FliL is essential for swarming in Proteus spp (Lee et al., 2013).

It has been reported that SecA is involved in translocation of bacterial secretory proteins out of the bacterial plasma membrane through $\mathrm{T} 5 \mathrm{a} S$ (Kim et al., 2014). Thus the decreased SecA expression by $\mathrm{C} 3 \mathrm{G}$ offers a mechanistic explanation as to why $\mathrm{C} 3 \mathrm{G}$ induces intracellular accumu- lation of VacA. We already developed SecA-specific antibodies in our previous study (Kim et al., 2014), and it was used to determine SecA protein levels in this study. SecA expression was decreased in the $\mathrm{C} 3 \mathrm{G}$ treated group in a dose-dependent manner (Fig. 3A and 3B). We found that the level of secreted VacA in the culture supernatant was decreased (Fig. 3C and 3D).

\section{Acknowledgements}

This paper was supported by the Semyung University Research Grant of 2013. 


\section{Conflict of interest}

The authors declare that there is no conflict of interests regarding the publication of this article.

\section{REFERENCES}

Alm RA, Ling LS, Moir DT, King BL, Brown ED, Doig PC, Smith DR, Noonan B, Guild BC, deJonge BL, Carmel G, Tummino PJ, Caruso A, Uria-Nickelsen M, Mills DM, Ives C, Gibson R, Merberg D, Mills SD, Jiang Q, Taylor DE, Vovis GF, Trust TJ. Genomic-sequence comparison of two unrelated isolates of the human gastric pathogen Helicobacter pylori. Nature. 1999. 14: 176-180

Backert S, Kwok T, Schmid M, Selbach M, Moese S, Peek RM Jr, König W, Meyer TF, Jungblut PR. Subproteomes of soluble and structure-bound Helicobacter pylori proteins analyzed by two-dimensional gel electrophoresis and mass spectrometry. Proteomics. 2005. 5: 1331-1345.

Censini S, Lang C, Crabtree JE, Ghiara P, Borodovsky M, Rappuoli R, Covacci A. cag pathogenicity island of Helicobacter pylori encodes type I-specific and disease-associated virulence factors. Proc Natl Acad Sci U S A. 1996. 93: 14648-14653.

Cho MJ, Jeon BS, Park JW, Jung TS, Song JY, Lee WK, Choi YJ, Choi SH, Park SG, Park JU, Choe MY, Jung SA, Byun EY, Baik SC, Youn HS, Ko GH, Lim D, Rhee KH. Identifying the major proteome components of Helicobacter pylori strain 26695. Electrophoresis. 2002. 23: 1161-1173.

Cover TL, Cao P, Lind CD, Tham KT, Blaser MJ. Correlation between vacuolating cytotoxin production by Helicobacter pylori isolates in vitro and in vivo. Infect Immun. 1993. 61: 5008-5012.

Cover TL, Blanke SR. Helicobacter pylori VacA, a paradigm for toxin multifunctionality. Nat Rev Microbiol. 2005. 3: 320-332.

Doig P, Austin JW, Kostrzynska M, Trust TJ. Production of a conserved adhesin by the human gastroduodenal pathogen Helicobacter pylori. J Bacteriol. 1992. 174: 2539-2547.

Eaton KA, Suerbaum S, Josenhans C, Krakowka S. Colonization of gnotobiotic piglets by Helicobacter pylori deficient in two flagellin genes. Infect Immun. 1996. 64: 2445-2448.

Glocker E, Lange C, Covacci A, Bereswill S, Kist M, Pahl HL. Proteins encoded by the cag pathogenicity island of Helicobacter pylori are required for NF-kappaB activation. Infect Immun. 1998. 66: 2346-2348.

Gobert AP, Mersey BD, Cheng Y, Blumberg DR, Newton JC,
Wilson KT. Cutting edge: urease release by Helicobacter pylori stimulates macrophage inducible nitric oxide synthase. J Immunol. 2002. 15: 6002-6006.

González L, Marrero K, Reyes O, Rodríguez E, Martínez L, Rodríguez BL. Cloning and expression of a recombinant CagA-gene fragment of Helicobacter pylori and its preliminary evaluation in serodiagnosis. Biomedica. 2013. 33: 546 $-553$

Israel DA, Salama N, Arnold CN, Moss SF, Ando T, Wirth HP, Tham KT, Camorlinga M, Blaser MJ, Falkow S, Peek RM Jr. Helicobacter pylori strain-specific differences in genetic content, identified by microarray, influence host inflammatory responses. J Clin Invest. 2001. 107: 611-620.

Ito Y, Azuma T, Ito S, Miyaji H, Hirai M, Yamazaki Y, Sato F, Kato T, Kohli Y, Kuriyama M. Analysis and typing of the vacA gene from cagA-positive strains of Helicobacter pylori isolated in Japan. J Clin Microbiol. 1997. 35: 1710-1721.

Jungblut PR, Bumann D, Haas G, Zimmy-Arndt U, Holland P, Lamer S, Siejak F, Aebischer A, Meyer TF. Comparative proteome analysis of Helicobacter pylori. Mol Microbiol. 2000. 36: 710-725.

Kim SH, Park M, Woo HJ, Tharmalingam M, Lee G, Rhee KJ, Eom YB, Han SI, Seo WD, Kim JB. Inhibitory Effects of Anthocyanins on Secretion of Helicobacter pylori CagA and VacA Toxins. Int J Med Sci. 2012. 9: 838-842.

Kim SH, Woo HJ, Park M, Rhee KJ, Moon C, Lee DS, Seo WD Kim JB. Cyanidin 3-O-glucoside reduces Helicobacter pylori VacA-induced cell death of gastric KATO III cells through inhibition of the SecA pathway. Int J Med Sci. 2014. 11: 742 $-747$.

Klimovich AV, Samoǐlovich MP, Suvorov AN. Development and characterization of Helicobacter pylori CagA recombinant fragments. Zh Mikrobiol Epidemiol Immunobiol. 2010. 2: 74 -79 .

Lee YY, Belas R. Loss of FliL alters Proteus mirabilis surface sensing and temperature-dependent swarming. J Bacteriol. 2015. 197: 159-173.

Lee YY, Patellis J, Belas R. Activity of Proteus mirabilis FliL is viscosity dependent and requires extragenic DNA. J Bacteriol. 2013. 195: 823-832.

Lock RA, Coombs GW, McWilliams TM, Pearman JW, Grubb WB, Melrose GJ, Forbes GM. Proteome analysis of highly immunoreactive proteins of Helicobacter pylori. Helicobacter. 2002. 7: 175-182.

Megraud F, Neman-Simha V, Brûgmann D. Further evidence of 
the toxic effect of ammonia produced by Helicobacter pylori urease on human epithelial cells. Infect Immun. 1992. 60: 1858 $-1863$.

Meyer-ter-Vehn T, Covacci A, Kist M, Pahl HL. Helicobacter pylori activates mitogen-activated protein kinase cascades and induces expression of the proto-oncogenes $c$-fos and c-jun. J Biol Chem. 2000. 275: 16064-16072.

Park JW, Song JY, Lee SG, Jun JS, Park JU, Chung MJ, Ju JS, Nizamutdinov D, Chang MW, Youn HS, Kang HL, Baik SC, Lee WK, Cho MJ, Rhee KH. Quantitative analysis of representative proteome components and clustering of Helicobacter pylori clinical strains. Helicobacter. 2006. 11: 533-543.

Rassow J. Helicobacter pylori vacuolating toxin A and apoptosis. Cell Commun Signal. 2011. 9: 26.

Selbach M, Moese S, Meyer TF, Beckert S. Functional analysis of the Helicobacter pylori cag pathogenicity island reveals both VirD4-CagA-dependent and VirD4-CagA-independent mechanisms. Infect Immun. 2002. 70: 665-671.

Shaffer CL, Gaddy JA, Loh JT, Johnson EM, Hill S, Hennig EE,
McClain MS, McDonald WH, Cover TL. Helicobacter pylori exploits a unique repertoire of type IV secretion system components for pilus assembly at the bacteria-host cell interface. PLoS Pathog. 2011. 7: e1002237.

Tomb JF, White O, Kerlavage AR, Clayton RA, Sutton GG, Fleischmann RD, Ketchum KA, Klenk HP, Gill S, Dougherty BA, Nelson K, Quackenbush J, Zhou L, Kirkness EF, Peterson S, Loftus B, Richardson D, Dodson R, Khalak HG, Glodek A, McKenney K, Fitzegerald LM, Lee N, Adams MD, Hickey EK, Berg DE, Gocayne JD, Utterback TR, Peterson JD, Kelley JM, Cotton MD, Weidman JM, Fujii C, Bowman C, Watthey L, Wallin E, Hayes WS, Borodovsky M, Karp PD, Smith HO, Fraser CM, Venter JC. The complete genome sequence of the gastric pathogen Helicobacter pylori. Nature. 1997. 7: 539-547.

Waidner D, Greiner S, Odenbreit S. Essential role of ferritin Pfr in Helicobacter pylori iron metabolism and gastric colonization. Infect Immun. 2002. 70: 3923-3929. 